\title{
Cultivable bacterial diversity and early plant growth promotion by the traditional organic formulations prepared using organic waste materials
}

\author{
Rangasamy Anandham ${ }^{1,2} \cdot$ Nagaiah Premalatha ${ }^{1} \cdot$ Hyeong Jin Jee ${ }^{2} \cdot$ \\ Hang Yeon Weon ${ }^{3}$ - Soon Wo Kwon ${ }^{3}$ - Ramasamy Krishnamoorthy ${ }^{1}$. \\ Pandiyan Indira Gandhi ${ }^{4}$ Yong Ki Kim ${ }^{2}$ Nellaiappan Olaganathan Gopal ${ }^{1}$
}

Received: 2 June 2015/Accepted: 5 October 2015/Published online: 9 November 2015

(c) The Author(s) 2015. This article is published with open access at Springerlink.com

\begin{abstract}
Purpose Traditional organic formulations are widely used as a plant growth promoters; however, the knowledge on the microbial aspect of traditional organic formulations is still limited. The aim of this study was to illustrate the cultivable bacterial diversity of various traditional organic formulations and their potential for early plant growth promotion.

Methods Five different traditional organic formulations such as $100 \%$ panchagavya, $33 \%$ panchagavya, plant extract with native microorganisms, commercial organic fertilizer extract with two percent leaf soil extract and commercial organic fertilizer extract with $2 \%$ yogurt were prepared and used in this study. The liquid fraction of these traditional organic formulations were used to analyze the beneficial effect on plant growth by seed treatment and foliar applications.
\end{abstract}

Electronic supplementary material The online version of this article (doi:10.1007/s40093-015-0107-1) contains supplementary material, which is available to authorized users.

Rangasamy Anandham

anandhamranga@gmail.com

1 Department of Agricultural Microbiology, Agricultural College and Research Institute, Tamil Nadu Agricultural University, Madurai 625 104, Tamil Nadu, India

2 Organic Agriculture Division, National Academy of Agricultural Science, Rural Development Administration, Suwon 441-707, Republic of Korea

3 Korean Agricultural Culture Collection, National Agro Biodiversity Center, National Academy of Agricultural Science, Rural Development Administration, Suwon 441-707, Republic of Korea

4 Regional Research Station, Tamil Nadu Agricultural University, Vridhachalam 606 001, Tamil Nadu, India
Results Bacterial 16SrDNA analysis revealed that the isolates fell into forty-three different genera, which can be grouped into seven different classes, such as Alphaproteobacteria, Actinobacteria, Bacilli (or Firmibacteria), Betaproteobacteria, Cytophagia, Flavobacteriia and Gammaproteobacteria. Higher bacterial diversity was observed in cow dung followed by 33 and $100 \%$ panchagavya. Radish and Chinese cabbage seed germination and growth were significantly improved by traditional organic formulations compared to control.

Conclusion The results of this study showed that the bacterial diversity changes depend on the type and concentration of ingredients used in traditional organic formulations. Substantial increase in plant growth by the traditional organic formulations indicates the suitability of using these organic preparations in eco-friendly agriculture.

Keywords Eubacterial diversity - Organic farming · Organic formulations $\cdot$ Panchagavya . Plant growthpromoting bacteria

\section{Introduction}

Intensive agriculture depends on expensive chemical inputs from off farm, which generates lot of pollutants and affects environment (Horrigan et al. 2002). Due to the negative impact of chemical inputs, organic farming gained more attention from last few decades (Badgley et al. 2007). The Food and Agricultural Organization of the United Nations (FAO) estimated that the area under organic agriculture was 37.2 million ha in 2011, which was three times higher than that of 1999 (FAO 2013). In organic farming, synthetic pesticides, mineral fertilizers, genetically modified 
organisms and sewage sludge applications are strictly excluded. Nonetheless, biofertilizers or traditional organic formulations prepared by using organic materials/wastes are encouraged to use as a plant nutrition (Badgley et al. 2007). Numerous studies stated that the yield and quality of plant products produced by organic farming are considerably better than that of conventional farming (Chemura 2014; Oliveira et al. 2013; Luthria et al. 2010). Organic farming not only improves the quality of the food products, but it also improves the soil fertility. In a long-term study in Switzerland, organic farming with composted animal manure improved soil quality significantly as compared to conventional farming with mineral fertilizer (Maeder et al. 2002).

Traditional organic formulations may contain numerous plant growth-promoting bacteria (PGPB), which may enhance plant growth by nitrogen fixation, growth hormone production and control phytopathogens (Amalraj et al. 2013; Naik and Sreenivasa 2009). In many Asian countries, farmers formulate their own organic formulations by combining different organic materials and treating them by fermentation or composting. For example, in India, panchagavya $(\mathrm{PG})$ is one of the widely used traditional organic formulations, which is mostly prepared by farmers themselves. Panchagavya is a fermented product made from five ingredients obtained from cow, such as milk, urine, dung, curd and clarified butter (Amalraj et al. 2013). South Korean farmers use wild weed wineberry (Rubus phoenicolasius) extract with native microorganisms, which is prepared by mixing wild weed extract, salt, molasses and decomposed leaf soil extract. Thailand farmers use fermented plant extracts or fermented plant juices, which can promote plant growth and act as a biocontrol agent (Kantachote et al. 2009). Bokashi is a Japanese traditional organic formulation preparation which contains effective microorganisms (EM). Japanese first developed the EM concept during 1980s, and this preparation contains various PGPB and yeast (Yamada and $\mathrm{Xu}$ 2001). These traditional organic formulations have not been well characterized microbiologically.

In recent past, several culture-independent methods have been developed to illustrate higher percent of bacterial population than usually found with cultural-dependent methods (Videira et al. 2013). These culture-independent methods may give in-depth knowledge about bacterial diversity, but it is impossible to use this information to identify the physiology of particular bacterial strain, interaction between microorganisms and response of bacterial strains to different environmental conditions (Stewart 2012). However, the culture-dependent method can be more useful in studying bacterial physiology and their role in plant growth promotion (Palleroni 1997). In addition, a cultural-dependent method may be helpful in industrial applications such as developments of antibiotics or biofertilizers. Only a few reports elucidate the microbial population in different organic formulations prepared by farmers (Radha and Rao 2014; Amalraj et al. 2013; Girija et al. 2013). Recently, higher number of cultivable bacterial genera was obtained from the organic formulation prepared using fermented cow manure (Giannattasio et al. 2013). In addition, few novel and plant growth-promoting bacteria such as Larkinella bovis sp. nov. and Microbacterium suwonense sp. nov. were isolated from traditional organic formulations and tested for their plant growth promotion (Anandham et al. 2011a, b; Sreenivasa et al. 2009).

In this study, culture-dependent method was used to illustrate the bacterial diversity in various traditional organic formulations made from organic materials and evaluated the effect of organic formulations on early growth of radish and Chinese cabbage. Successfully cultivated bacterial isolates may be used to develop a microbial consortium to support sustainable agricultural practice in future.

\section{Materials and methods}

\section{Traditional organic formulations preparations}

Organic formulations such as $100 \%$ PG, $33 \%$ PG, plant extract with native microorganism (PNM), commercial organic fertilizer extract with $2 \%$ leaf soil extract (OLE) and commercial organic fertilizer extract with $2 \%$ yogurt (OY) were prepared and used in this study. Ingredients and their concentration of different traditional organic formulations are given in Table 1 .

Commercially available pelleted organic fertilizer (OF) extract was used to prepare OLE and OY. Pelleted OF contains $55 \%$ caster bean waste, $40 \%$ rice bran and $5 \%$ palm waste with the nutrient content of $45 \% \mathrm{~N}, 1.5 \% \mathrm{P}$ and $1.0 \% \mathrm{~K}$. For preparing an organic fertilizer extract, forty gram OF was boiled in $400 \mathrm{ml}$ of water (sterile distilled water) for $30 \mathrm{~min}$ and then the filtrate was collected using the filter paper (Whatman No. 2-90 mm). Leaf soil extract was prepared by mixing $20 \mathrm{~g}$ of soil [containing decomposed leaf, collected from the hilly region Gangwon Province of South Korea $\left(37^{\circ} 49^{\prime} 22.64^{\prime \prime} \mathrm{N}\right.$; $128^{\circ} 09^{\prime} 23.00^{\prime \prime} \mathrm{E}$ )] with $120 \mathrm{ml}$ of water (sterile distilled water) and shaken for $30 \mathrm{~min}$, then filtered through filter paper (Whatman No. 2-90 mm). The ingredients of the each traditional organic formulation were mixed in a flask and allowed for fermentation for 5 days in shaking condition $(120 \mathrm{rpm})$ at $30^{\circ} \mathrm{C}$. During fermentation, microorganisms can degrade the organic materials and enhance the production of organic formulations. All five organic 
Table 1 Ingredients and their concentrations of different organic formulations

\begin{tabular}{|c|c|c|c|c|}
\hline $100 \%$ PG & $33 \%$ PG & PNM & OLE & OY \\
\hline $\begin{array}{l}\text { Cow dung }(1.5 \mathrm{~g}) \\
\text { Cow urine }(4.5 \mathrm{ml}) \\
\text { Cow milk }(3.0 \mathrm{ml}) \\
\text { Yogurt }(3.0 \mathrm{~g}) \\
\text { Molasses }(4.5 \mathrm{~g}) \\
\text { Potato }(3.0 \mathrm{~g}) \text { and make } \\
\text { up to } 11 \text { with water }\end{array}$ & $\begin{array}{l}\text { Cow dung }(0.5 \mathrm{~g}) \\
\text { Cow urine }(1.49 \mathrm{ml}) \\
\text { Cow milk }(0.99 \mathrm{ml}) \\
\text { Yogurt }(0.99 \mathrm{~g}) \\
\text { Molasses }(4.5 \mathrm{~g}) \\
\text { Potato }(0.99 \mathrm{~g}) \text { and } \\
\text { make up to } 11 \text { with } \\
\text { water }\end{array}$ & $\begin{array}{l}0.2 \% \text { wild weed wineberry } \\
\text { extracts, } 0.1 \% \text { sodium } \\
\text { chloride } \\
0.5 \% \text { molasses and make up to } \\
11 \text { with water }\end{array}$ & $\begin{array}{l}40 \% \text { OF extract, } 2 \% \\
\text { molasses } \\
0.2 \% \text { sodium chloride } \\
2 \% \text { leaf soil extract and } \\
\text { make up to } 11 \text { with water }\end{array}$ & $\begin{array}{l}2 \% \text { yogurt } \\
40 \% \text { OF extract } \\
2 \% \text { molasses and make } \\
\text { up to } 11 \text { with water }\end{array}$ \\
\hline
\end{tabular}

formulations were separately filtered through a cloth filter (performed under aseptic condition to avoid contamination), and then, the liquid fraction was used for further experiments.

\section{Cultivable bacterial diversity analysis}

Bacteria were isolated from the liquid fraction of various traditional organic formulations using trypticase soybean agar (TSA; Difco), Lysogeny agar (LA; Difco) and $\mathrm{R}_{2} \mathrm{~A}$ agar (Difco). In addition, PG ingredients (cow urine, cow dung and cow milk) were also used for bacterial isolation (by serial dilution and plating) and diversity analysis. Isolated bacterial cultures (169 isolates) were grouped into different genera based on their short-length sequencing of 16S rDNA with 895F (CRCCTGGGGAGTRCRG), 47F (GCGCCAGGGAATTCTAAAAC) and 783R (ACCMGG GTATCTAATCCKG) primers. Only 96 bacterial isolates were selected (by avoiding duplicate within the treatments), and nearly full-length sequence of $16 \mathrm{~S}$ rDNA was sequenced for species-level identification. Genomic DNA of 96 bacterial isolates was extracted using Ultra Clean DNA isolation kit (MO BioLaboratories Inc., Carlsbad, CA, USA) and amplified using universal 16S rDNA primers (27F and 1492R). The $16 \mathrm{~S}$ rDNA nucleotide sequences were identified by PCR direct sequencing by fluorescent dye terminator method (ABI Prism ${ }^{\mathrm{TM}}$ Bigdye $\mathrm{e}^{\mathrm{TM}}$ Terminator cycle sequencing ready reaction kit v.3.1; Applied Biosystems, Foster, CA, USA), and the products were purified by Millipore-Montage dye removal kit (Beckman Coulter Inc., Fullerton, CA, USA). Finally, the products were run into an ABI3730XL capillary DNA sequencer ( $50 \mathrm{~cm}$ capillary). $16 \mathrm{~S}$ rDNA sequences from the automatic sequencer were aligned, and bacterial identities deduced by using the EzTaxon-e server (http:// eztaxon-e.ezbiocloud.net/) to ascertain their closest relatives. The sequences obtained in this study were submitted in GenBank, with the accession numbers from GQ246652 to GQ246748. 16S rDNA sequences were aligned using the CLUSTALW program, and the phylogenetic tree was constructed using MEGA version 6.0 (Tamura et al. 2013). Neighbor-joining tree was constructed with the bootstrap values of 1000 .

\section{Pathogen detection in organic formulations preparations and their ingredients}

Five traditional organic formulations and PG ingredients were tested for the presence of pathogens such as Staphylococci and Enterobacteriaceae using the STAPH PLUS (Thermo Fisher Scientific Inc., Waltham, MA, USA) and RapID One (Thermo Fisher Scientific Inc., Waltham, MA, USA), respectively, according to the manufacturers instruction.

\section{Plant growth experiments}

Radish (Raphanus sativus L. cultivar Hong Feng No. 1) and Chinese cabbage (Brassica rapa subsp. pekinensis cultivar Norangchusurk) seeds were surface sterilized and imbibed in $5 \mathrm{ml}$ liquid fraction of five different organic formulations with 0,50 and 100 times dilutions and incubated at $25 \pm 2{ }^{\circ} \mathrm{C}$ for $72 \mathrm{~h}$ for seed germination. The seeds were taken as germinated if the radicle emerges from the seeds. Three-day-old germinated seeds were transplanted into $40-\mathrm{L}$ pot containing $20-\mathrm{kg}$ pot mixture $(\mathrm{pH}$ $7.0 ; \quad \mathrm{EC}-1.2 ; \quad \mathrm{NH}_{4}{ }^{+} \mathrm{N}-170 \mathrm{mg} \mathrm{kg}^{-1} ; \quad \mathrm{NO}_{3}{ }^{-} \mathrm{N}-$ $110 \mathrm{mg} \mathrm{kg}^{-1} ;$ available $\mathrm{P}_{2} \mathrm{O}_{5}-300 \mathrm{mg} \mathrm{kg}^{-1} ; \mathrm{K}_{2} \mathrm{O}-$ $340 \mathrm{mg} \mathrm{kg}^{-1}$; CEC $-10 \mathrm{cmol}_{\mathrm{c}} \mathrm{kg}^{-1}$ ) and maintained for 30 days. Pot experiment was performed with sixteen treatments (five organic fertilizers with three dilutions and one control). The plants were irrigated once in 2 days until the pot mixture reached $70 \%$ of its water-holding capacity. Additional to seed treatment, $25 \mathrm{ml}$ of respective traditional organic formulations was sprayed on the plants until runoff using the handheld pneumatic sprayer, on seventh day after transplantation. In the case of control, sterile distilled water was sprayed to maintain the same conditions as other treatments. There were three replications for each treatment and arranged in a completely randomized block 
design in the greenhouse. Root length, shoot length and dry weight of the plants were measured 30 days after transplantation (DAT).

\section{Statistical analysis}

Data on microbial count and plant parameters were subjected to analysis of variance (ANOVA) and Duncan's multiple range test (DMRT) using the SAS package, version 9.1.3 (SAS Institute Inc., Cary, NC, USA) and tested significant differences at 0.05 . Data on plant growth of individual traditional organic formulation treatment and their dilutions were compared with control plants in order to find out the effect of traditional organic formulations on radish and Chinese cabbage growth. Microbial count data were $\log 10-$ transformed before statistical analysis. Heat map was constructed using Microsoft Excel conditional formatting.

\section{Results}

\section{Bacterial count and cultivable bacterial diversity of various traditional organic formulations and PG ingredients}

LA and TSA were found to support a higher number of bacterial group than that of R2A medium (Online Resource 1). No significant differences in bacterial count were observed among different organic formulations prepared and used in this study. Short-length sequencing of 169 bacterial isolates obtained from different organic formulations and PG ingredients (cow urine, cow dung and cow milk) revealed that the isolates were belonged to 43 different genera (Fig. 1). These 43 genera can be grouped into seven different classes, such as Alphaproteobacteria, Actinobacteria, Bacilli (or Firmibacteria), Betaproteobacteria, Cytophagia, Flavobacteriia and Gammaproteobacteria (Fig. 2). Fifty-four percentage of the cultivable bacterial population in $100 \%$ PG preparation was Bacilli (or Firmibacteria). In particular, Bacillus, Lactobacillus, Lactococcus, Leuconostoc and Lysinibacillus genera were dominated. The higher proportion of Alphaproteobacteria was observed in $33 \%$ PG followed by Firmibacteria and Betaproteobacteria. Other organic formulations such as PNM, OLE, OY and PG ingredients were found to be dominated by Firmibacteria and Alphaproteobacteria or Actinobacteria (Fig. 2). Higher number of cultivable bacterial species were observed in cow dung (54 species) followed by $33 \%$ (37 species) and $100 \%$ PG (28 species).

Out of 169 bacterial isolates, 96 were carefully selected for full-length sequencing by avoiding duplicates within the treatments. All sequenced isolates with closest neighbor and their accession numbers are given in Online Resource 2. Our sequencing results revealed that PG preparation had thirteen unique bacterial genera, which were belong to various PGPB and fermentative groups of bacteria. Azospirillum, Brevundimonas, Lactobacillus, Xenophilius, Xylophilus, Comamonas and Acetobacter are the representatives of PGPB genera found in PG preparation (Fig. 3).

\section{Pathogen detection in traditional organic formulations and their ingredients}

RapID STAPH PLUS system and RapID One analysis revealed the presence of Staphylococcus aureus and Escherichia coli in cow dung which was one of the ingredients in PG preparation, but those pathogens were not observed in PG organic formulations. In addition, 16S rDNA amplification confirmed the presence of foodborne pathogens (Shigella flexneri, Bergyella zoohelcum and Enterococcus durans) in cow dung and cow milk (Online Resource 2). However, these pathogens were not observed in 33 and $100 \%$ PG organic formulations.

\section{Germination assay and plant responses to different organic formulations and their dilution}

Germination percentage of radish and Chinese cabbage treated with different organic formulations is presented in Fig. 4. Dilution of $33 \%$ PG, PNM, OLE and OY fertilizers showed a significant increase in radish seed germination. On the other hand, traditional organic formulations did not show any significant increase in Chinese cabbage seed germination (Fig. 4).

Organic formulation-treated plants showed higher growth compared to control plants (except in $100 \%$ PG treatment). Zero times dilution of $100 \%$ PG had negative impact on plant growth, which registered the lower root length, shoot length and dry weight of radish than that of diluted treatments (Fig. 5; Online Resource 3, 4). Higher root length of radish $(25.6 \mathrm{~cm})$ and Chinese cabbage $(33.33 \mathrm{~cm})$ was observed in OY (50 times diluted) and $33 \%$ PG (zero times diluted) treatment, respectively (Online Resource 3). Radish and Chinese cabbage shoots length was found to be higher in $33 \%$ PG and OY (zero times diluted) treatment, respectively (Online Resource 4). Higher dry matter accumulation was found in OLEtreated (100 times diluted) radish and Chinese cabbage plants (Fig. 5). Dry weight of radish was significantly improved by $100 \%$ PG, $33 \%$ PG, PNM and OLE treatments than that of control plants. Traditional organic formulations have no significant impact on Chinese cabbage dry weight. 
Fig. 1 Heat map shows the number of bacterial species isolated from different organic formulations and their ingredients. $T 1100 \%$ panchagavya; T2 $33 \%$ panchagavya; T3 plant extract with native microorganisms; $T 4$ commercial organic fertilizer extract with $2 \%$ leaf soil extract; $T 5$ commercial organic fertilizer extract with $2 \%$ yogurt; $T 6$ cow urine; $T 7$ cow dung; $T 8$ cow milk

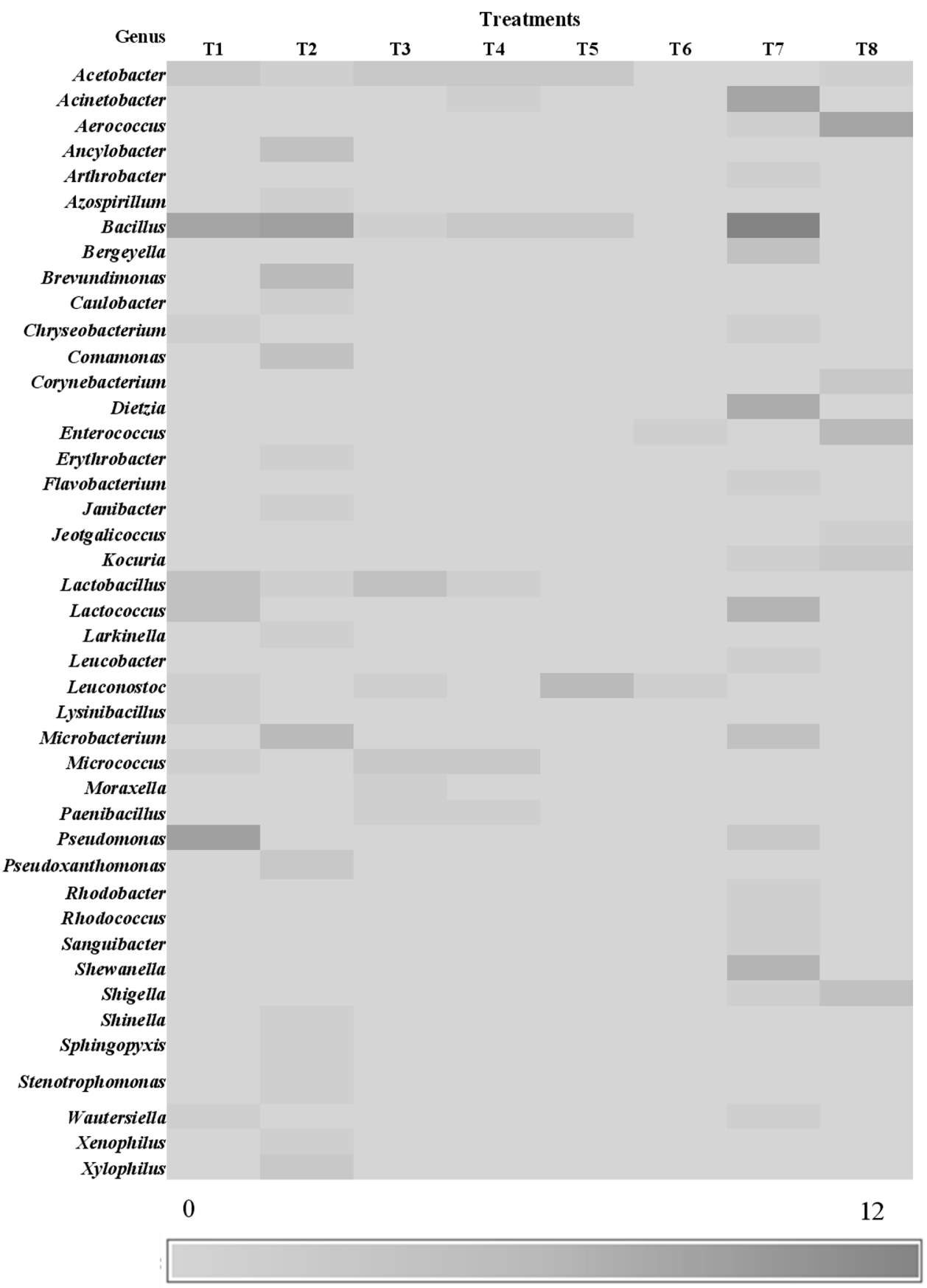

\section{Discussion}

Farmer utilizes locally available organic materials for preparing organic formulations, and there are many welldeveloped traditional organic formulations which are available worldwide, but most of them are unpopular. Chemical and microbiological aspect of many traditional organic formulations is not well studied. Recently, nuclear magnetic resonance analysis of organic formulations revealed the presence of various bioactive compounds, which helps in plant growth improvement (Spaccini et al.
2012). In this work, we have chosen five different traditional organic formulations such as $100 \% \mathrm{PG}, 33 \% \mathrm{PG}$, PNM, OLE and OY to analyze microbiological aspects and the effect of organic formulations on early plant growth was also illustrated.

Three diverse microbiological media have been used to obtain higher number of cultivable bacterial population from different organic formulations. This cultivation-dependent approach exhibited the presence of novel bacterial isolates such as $L$. bovis sp. nov. and $M$. suwonense sp. nov. in organic formulations and PG ingredients, respectively 
Fig. 2 Class and genus-level distribution of bacteria in different organic formulations and their ingredients.

a Alphaproteobacteria;

b Actinobacteria; c Bacilli (or

Firmibacteria);

d Betaproteobacteria;

e Cytophagia; f Flavobacteriia;

g Gammaproteobacteria.

Larger circle represents

percentages of different classes of bacteria present in organic formulations and ingredients.

Partitioning of small circle represents number of genera present in a particular class
$100 \%$ panchagavya

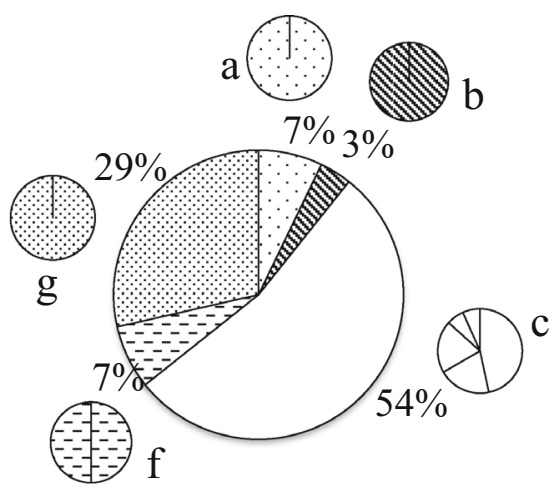

PNM

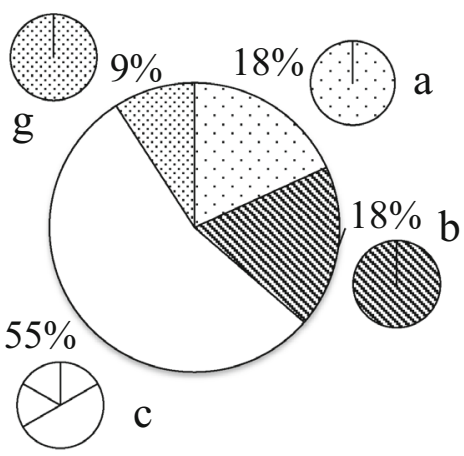

OY

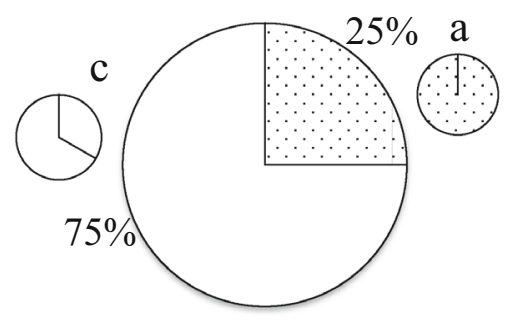

\section{Cow dung}

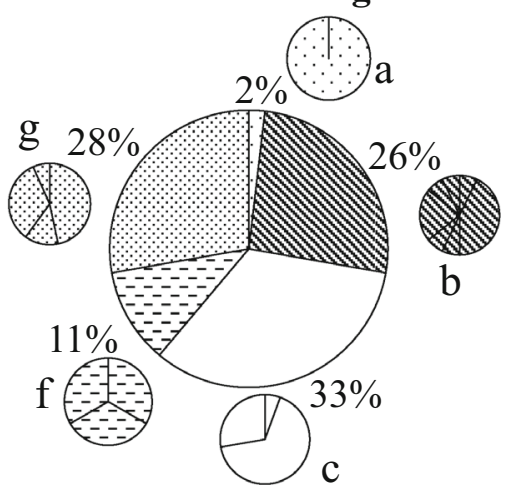

$33 \%$ panchagavya

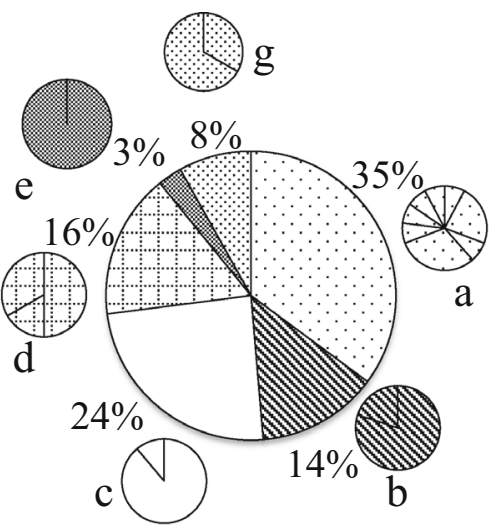

OLE

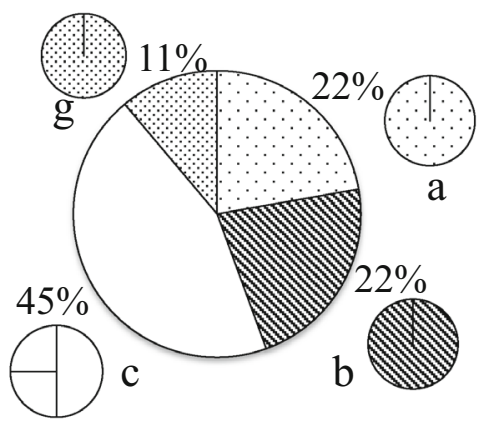

Cow urine

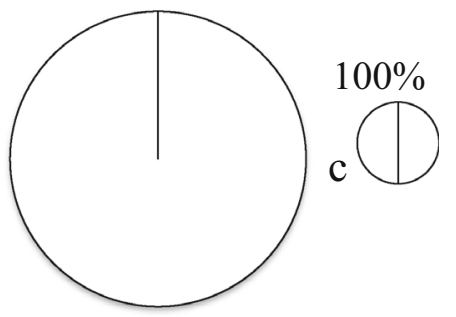

Cow milk

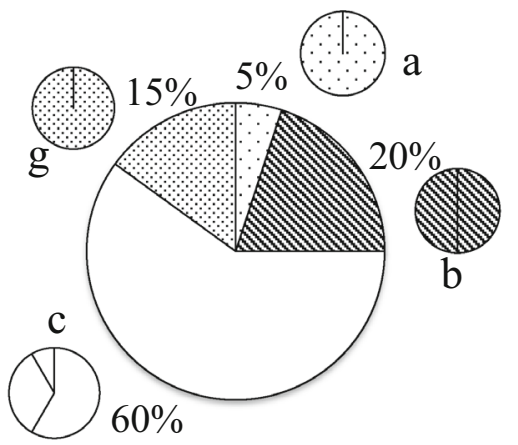


Fig. 3 Neighbor-joining phylogenetic tree shows the relationship among the bacterial species isolated from $33 \%$ panchagavya preparations (highlighted in bold) and their closest neighbors. Tree was constructed using near-fulllength sequences of bacterial 16S rDNA sequences with 1000 bootstraps values

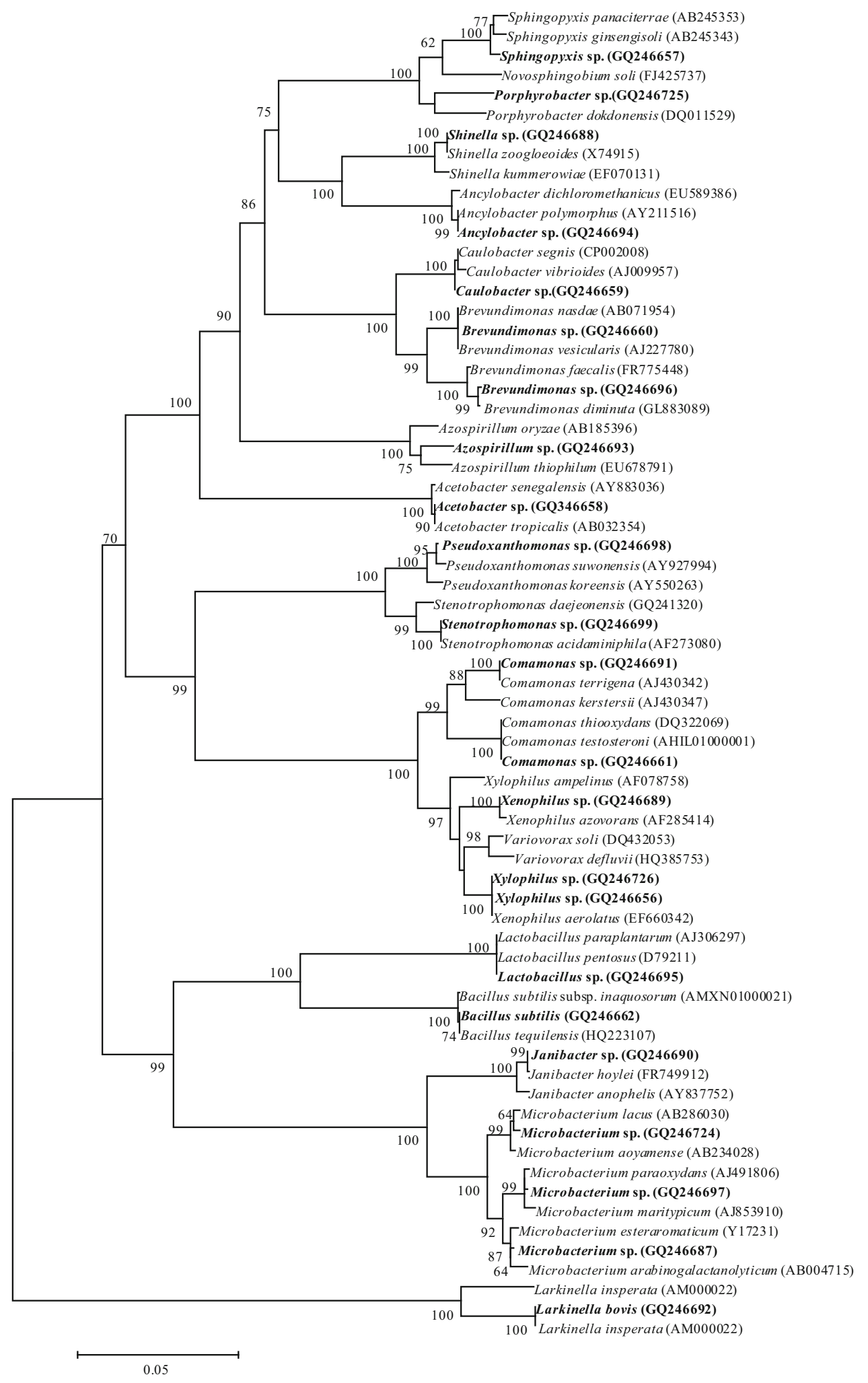

(Anandham et al. 2011a, b). Fermentation process during the preparation of traditional organic formulations encourages different group of microorganisms to develop (Yan et al. 2013). These microorganisms may be grouped into three different groups such as plant growth promoters, fermentative microorganisms and antibiotic producers based on their functions. Fermentative group of microorganisms break down complex nutrients into simple 
(a)

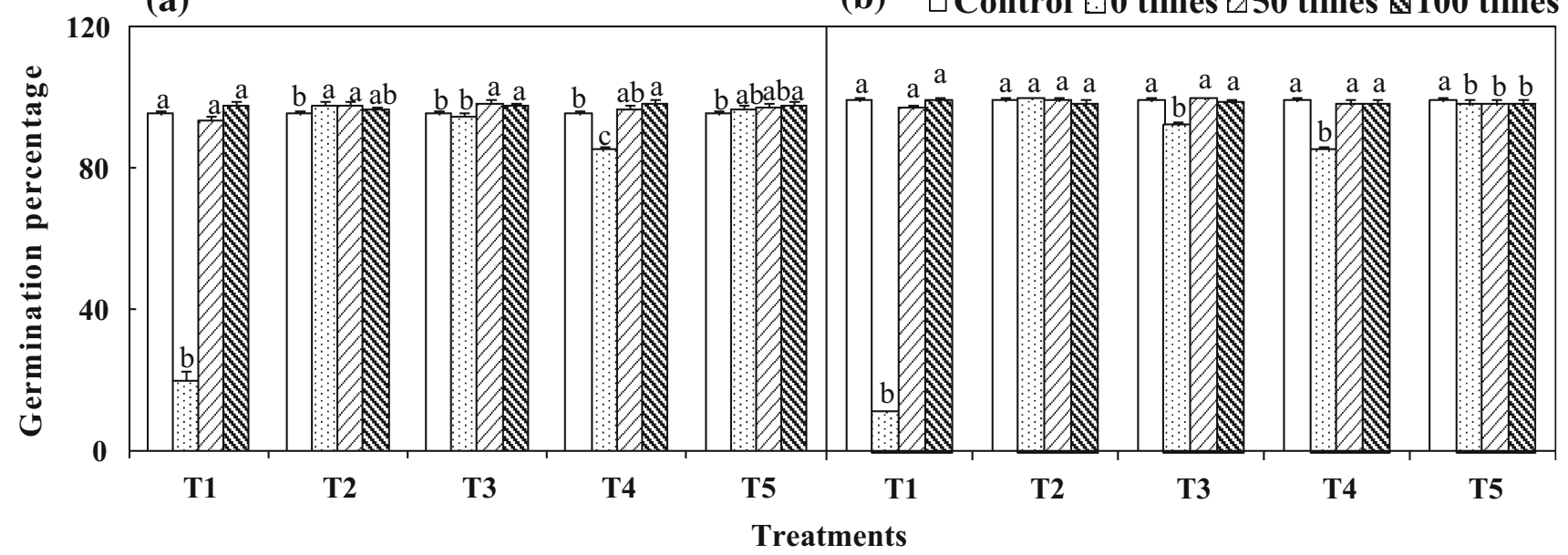

Fig. 4 Effect of seed treatment of different organic formulations on radish (a) and Chinese cabbage (b) seed germination percentage under in vitro condition. T1 $100 \%$ panchagavya; T2 $33 \%$ panchagavya; T3 plant extract with native microorganisms; T4 commercial organic fertilizer extract with $2 \%$ leaf soil extract; T5 commercial organic fertilizer extract with $2 \%$ yogurt. Control, 0, 50 and 100 times dilution of organic formulations are represented in different shades. Values are mean \pm standard error (SE) of three replications, and same letters in each treatment are not significantly different from each other at $P<0.05$ according to Duncan's multiple range test (DMRT) (a)

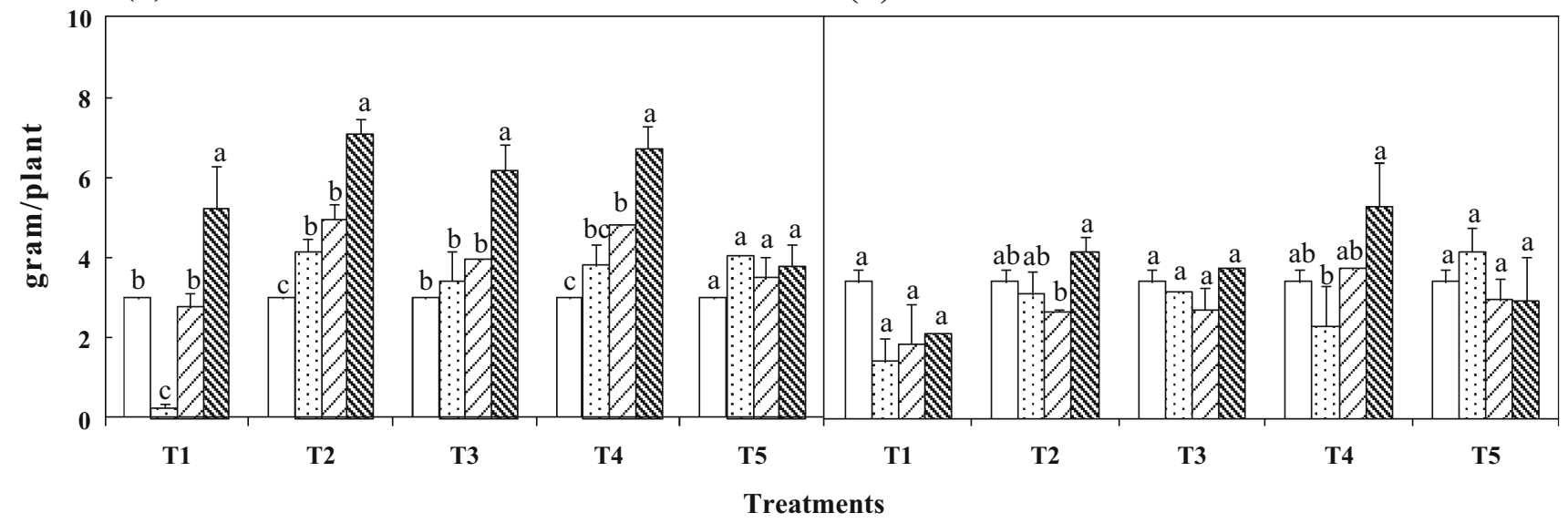

Fig. 5 Effect of different organic formulations on dry weight of radish (a) and Chinese cabbage (b) under pot culture condition. T1 $100 \%$ panchagavya; T2 $33 \%$ panchagavya; T3 plant extract with native microorganisms; $T 4$ commercial organic fertilizer extract with $2 \%$ leaf soil extract; T5 commercial organic fertilizer extract with

nutrients, and antibiotic producers inhibit pathogenic bacterial growth (Yadav et al. 2013; Gea et al. 2009). On the other hand, PGPB harbored in the organic formulations improves plant growth by various mechanisms (Naik and Sreenivasa 2009). PGPB are the group of bacteria found in the rhizosphere and/or phyllosphere region of plants, which can enhance plant growth by direct and indirect mechanisms (Vacheron et al. 2013). Presence of various PGPB and slow release of nutrients are the two main reasons for
$2 \%$ yogurt. Control, 0, 50 and 100 times of dilution organic formulations are represented in different shades. Values are mean $\pm \mathrm{SE}$ of three replications, and same letters in each treatment are not significantly different from each other at $P<0.05$ according to DMRT

plant growth promotion and improving soil health by organic formulations (Amalraj et al. 2013).

In our study, total bacterial populations in raw and processed organic formulations were not significantly changed. However, bacterial genus/species between organic formulations and their raw ingredients were changed. This clearly indicates the occurrence of bacterial succession during fermentation process. In recent past, use of pyrosequencing technique revealed the presence of 142 bacterial genera in 
cow dung, which includes cultivable and non-cultivable bacteria (Dowd et al. 2008). However, only 19 cultivable bacterial genera from the cow dung were able to cultivate under laboratory condition. Less number of cultivable bacterial genera obtained in this study proven the uncultivable nature of numerous bacterial genera in common laboratory media (Joseph et al. 2003). Other than 169 bacterial isolates, we were also obtained some yeast strains, which might also played an important role in the breakdown of complex sugars into simple components in the fermentation process during organic formulations preparation (Kantachote et al. 2009).

One of the PG ingredients (cow dung) was considered to be an carrier for foodborne pathogens like $S$. aureus, E. coli, Salmonella sp. and Campylobacter sp. (Simujide et al. 2013). In line with this, our results also showed the presence of $S$. aureus and E. coli pathogens in cow dung. However, these pathogens were eliminated by fermentation process during organic formulations preparation. Similar to our results, El Fels et al. (2015) showed the elimination of coliforms during the composting of organic waste material. Particularly, antibiotic-producing microorganisms in organic formulations might have played an important role in eliminating foodborne pathogens and phytopathogens (Qiu et al. 2012). Similar to this, composting of cow dung was also reported to be effective in removing foodborne pathogens such as $S$. aureus and E. coli (Simujide et al. 2013). Recently, Liu et al. (2013) reported that the inoculation of antagonistic bacteria with organic formulations was found to be effective in phytopathogen control.

Dominance nature of Firmibacteria in organic formulations used in this study might be due to the use of soil and plant extracts as one of the ingredients. Recently, Chen et al. (2013) reported the dominance of Firmibacteria in plant and soil ecosystem. Similarly, Firmibacteria was also dominated in compost prepared using agricultural waste materials (Chandna et al. 2013). PGPB such as Acetobacter sp. (Sevilla et al. 2001), Azospirillum sp. (Fages and Arsac 1991) and Brevundimonas sp. (Kumar and Gera 2014) found in $33 \%$ PG were belong to Alphaproteobacteria. In addition, Firmibacteria class PGPB like Bacillus subtilis (Mohamed and Gomaa 2012) and Lactobacillus sp. (Limanska et al. 2013) were also observed (Fig. 3). Soil bacteria like Micrococcus sp., Paenibacillus sp. and Acetobacter sp. were dominated in PNM and OLE preparations. This may be due to the use of soil as one of the ingredient in these organic formulations preparations. Whereas Leuconostoc mesenteroides was found to be dominant in treatment containing OFE with $2 \%$ yogurt, this bacterial species was mainly involved in milk fermentation process (Kihal et al. 2007).

Traditional organic formulations exhibited a significant positive impact on radish growth except $100 \%$ PG. In line with this, many authors reported the beneficial effect of organic formulations on plant growth improvement (Naik and Sreenivasa 2009; Amalraj et al. 2013). Similarly, Pigeon pea treated with PG, vermicompost and farm yard manure improved plant growth compared to control, but the results were not significantly different among various organic formulations used (Gupta et al. 2014; Amalraj et al. 2013). Organic compost application significantly improved the dry biomass accumulation in wheat (Carpenter-Boggs et al. 2000). In agreement with this, our study also showed significantly higher radish dry biomass on organic formulations application. One hundred percent PG-treated plants showed significantly lower radish root length, shoot length, dry weight and root length of Chinese cabbage compared to that of diluted treatments and control. This might be due to the presence of plant growth inhibitors, acidic $\mathrm{pH}$ (5.6) and nutrients in undiluted $100 \%$ PG. In line with this, Kadam and Pathade (2014) also showed the negative effect of higher concentration of vermicompost application on French bean growth compared to lower concentration of compost application. There were no consistent positive results for plant growth improvement on dilution of original organic formulations, except for $100 \%$ PG. Similarly, different rate of compost application to vegetable crops showed no significant differences in plant growth between high and low concentrations (Chang et al. 2007).

\section{Conclusion}

This study illustrated the cultivable bacterial diversity of organic formulations traditionally prepared and used by farmers. The results of this study revealed that the bacterial diversity changes depend on the type and concentration of ingredients used in organic formulations. Significant increases in plant growth by organic formulations indicate the appropriateness of substituting organic formulations in the place of chemical fertilizers to enhance eco-friendly agriculture. Future study focusing on the plant growthpromoting characters of the isolates and symbiotic association among the isolates might help in developing microbial consortium for sustainable agriculture.

Acknowledgments This work was supported by the National Academy of Agricultural Science (NAAS) and the Rural Development Administration (RDA), Republic of Korea. R.A. thanks RDA for award of a postdoctoral fellowship.

Open Access This article is distributed under the terms of the Creative Commons Attribution 4.0 International License (http://crea tivecommons.org/licenses/by/4.0/), which permits unrestricted use, distribution, and reproduction in any medium, provided you give appropriate credit to the original author(s) and the source, provide a link to the Creative Commons license, and indicate if changes were made. 


\section{References}

Amalraj ELD, Praveen Kumar G, Mir Hassan Ahmed SK, Abdul R, Kishore N (2013) Microbiological analysis of panchagavya, vermicompost, and FYM and their effect on plant growth promotion of pigeon pea (Cajanus cajan L.) in India. Org Agric 3:23-29

Anandham R, Kwon SW, Weon HY, Kim SJ, Kim YS, Gandhi PI, Kim YK, Jee HJ (2011a) Larkinella bovis sp. nov., isolated from fermented bovine products, and emended descriptions of the genus Larkinella and of Larkinellainsperata Vancanneyt et al. 2006. Int J Syst Evol Microbiol 61:30-34

Anandham R, Tamura T, Hamada M, Weon HY, Kim SJ, Kim YS, Suzuki K, Kwon SW (2011b) Microbacterium suwonense sp. nov., isolated from cow dung. J Microbiol 49:852-856

Badgley C, Moghtader J, Quintero E, Zakem E, Chappell MJ, Vazquez KA, Samulon A, Perfecto I (2007) Organic agriculture and the global food supply. Renew Agric Food Syst 22:86-108

Carpenter-Boggs L, Reganold JP, Kennedy AC (2000) Biodynamic preparations: short-term effects on crops, soils, and weed populations. Am J Altern Agric 15:110-118

Chandna P, Mallik S, Kuhad RC (2013) Assessment of bacterial diversity in agricultural by-product compost by sequencing of cultivated isolates and amplified rDNA restriction analysis. Appl Microbiol Biotechnol 97:6991-7003

Chang EH, Chung RS, Tsai YH (2007) Effect of different application rates of organic fertilizer on soil enzyme activity and microbial population. Soil Sci Plant Nutr 53:132-140

Chemura A (2014) The growth response of coffee (Coffea arabica L) plants to organic manure, inorganic fertilizers and integrated soil fertility management under different irrigation water supply levels. Int J Recycl Org Waste Agric 3:59. doi:10.1007/s40093014-0059-x

Chen F, Wang M, Zheng Y, Li S, Wang H, Han D, Guo S (2013) The effect of biocontrol bacteria on rhizosphere bacterial communities analyzed by plating and PCR-DGGE. Curr Microbiol 67:177-182

Dowd SE, Callaway TR, Wolcott RD, Sun Y, McKeehan T, Hagevoort RG, Edrington TS (2008) Evaluation of the bacterial diversity in the feces of cattle using $16 \mathrm{~S}$ rDNA bacterial tagencoded FLX amplicon pyrosequencing (bTEFAP). BMC Microbiol 8:125. doi:10.1186/1471-2180-8-125

El Fels L, Ouhdouch Y, Hafidi M (2015) Use of the co-composting time extract agar to evaluate the microbial community changes during the co-composting of activated sludge and date palm waste. Int J Recycl Org Waste Agric 4:95-103

Fages J, Arsac JF (1991) Sunflower inoculation with Azospirillum and other plant growth promoting rhizobacteria. Plant Soil 137:87-90

FAO (2013) Statistical yearbook world food and agriculture. Food and Agriculture Organization of the United Nations, Rome, pp 1-307

Gea FJ, Navarro MJ, Tello JC (2009) Potential application of compost teas of agricultural wastes in the control of the mushroom pathogen Verticillium fungicola. J Plant Dis Prot 116:271-273

Giannattasio M, Vendramin E, Fornasier F, Alberghini S, Zanardo M, Stellin F, Concheri G, Stevanato P, Ertani A, Nardi S, Rizzi V, Piffanelli P, Spaccini R, Mazzei P, Piccolo A, Squartini A (2013) Microbiological features and bioactivity of a fermented manure product (preparation 500) used in biodynamic agriculture. J Microbiol Biotechnol 23:644-651

Girija D, Deepa K, Xavier F, Antony I, Shidhi PR (2013) Analysis of cow dung microbiota-a metagenomic approach. Indian $\mathrm{J}$ Biotechnol 12:372-378

Gupta R, Yadav A, Garg VK (2014) Influence of vermicompost application in potting media on growth and flowering of marigold crop. Int J Recycl Org Waste Agric 3:47. doi:10. 1007/s40093-014-0047-1

Horrigan L, Lawrence RS, Walker P (2002) How sustainable agriculture can address the environmental and human health harms of industrial agriculture. Environ Health Perspect 110:445-456

Joseph SJ, Hugenholtz P, Sangwan P, Osborne CA, Janssen PH (2003) Laboratory cultivation of widespread and previously uncultured soil bacteria. Appl Environ Microbiol 69:7210-7215

Kadam D, Pathade G (2014) Effect of tendu (Diospyros melanoxylon RoxB.) leaf vermicompost on growth and yield of French bean (Phaseolus vulgaris L.). Int J Recycl Org Waste Agric 3:44. doi:10.1007/s40093-014-0044-4

Kantachote D, Kowpong K, Charernjiratrakul W, Pengnoo A (2009) Microbial succession in a fermenting of wild forest noni (Morinda coreia Ham) fruit plus molasses and its role in producing a liquid fertilizer. Electron J Biotechnol 12. doi:10. 2225/vol12-issue3-fulltext-12

Kihal M, Prevost H, Henni DE, Benmechernene Z, Divies C (2007) Carbon dioxide production by Leuconostoc mesenteroides grown in single and mixed culture with Lactococcus lactis in skimmed milk. World J Dairy Food Sci 2:62-68

Kumar V, Gera R (2014) Isolation of a multi-trait plant growth promoting Brevundimonas sp. and its effect on the growth of Btcotton. 3 Biotech 4:97-101

Limanska N, Ivanytsia T, Basiul O, Krylova K, Biscola V, Chobert JM, Ivanytsia V, Haertle T (2013) Effect of Lactobacillus plantarum on germination and growth of tomato seedlings. Acta Physiol Plant 35:1587-1595

Liu Y, Shi J, Feng Y, Yang X, Li X, Shen Q (2013) Tobacco bacterial wilt can be biologically controlled by the application of antagonistic strains in combination with organic fertilizer. Biol Fertil Soils 49:447-464

Luthria D, Singh AP, Wilson T, Vorsa N, Banuelos GS, Vinyard BT (2010) Influence of conventional and organic agricultural practices on the phenolic content in eggplant pulp: plant-toplant variation. Food Chem 121:406-411

Maeder P, Fliebbach A, Dubois D, Gunst L, Fried P, Niggli U (2002) Soil fertility and biodiversity in organic farming. Science 296:1694-1697

Mohamed HI, Gomaa EZ (2012) Effect of plant growth promoting Bacillus subtilis and Pseudomonas fluorescens on growth and pigment composition of radish plants (Raphanus sativus) under $\mathrm{NaCl}$ stress. Photosynthetica 50:263-272

Naik N, Sreenivasa MN (2009) Influence of bacteria isolated from panchagavya on seed germination and seed vigour in wheat. Karnataka J Agric Sci 22:231-232

Oliveira AB, Moura CFH, Gomes Filho E, Marco CA, Urban L, Miranda MRA (2013) The impact of organic farming on quality of tomatoes is associated to increased oxidative stress during fruit development. PLoS One 8. doi:10.1371/journal.pone.0056354

Palleroni NJ (1997) Prokaryotic diversity and the importance of culturing. Antonie Van Leeuwenhoek J Microbiol 72:3-19

Qiu M, Zhang R, Xue C, Zhang S, Li S, Zhang N, Shen Q (2012) Application of bio-organic fertilizer can control Fusarium wilt of cucumber plants by regulating microbial community of rhizosphere soil. Biol Fertil Soils 48:807-816

Radha TK, Rao DLN (2014) Plant growth promoting bacteria from cow dung based biodynamic preparations. Indian J Microbiol 54:413-418

Sevilla M, Burris RH, Gunapala N, Kennedy C (2001) Comparison of benefit to sugarcane plant growth and ${ }^{15} \mathrm{~N}_{2}$ incorporation following inoculation of sterile plants with Acetobacter diazotrophicus wild-type and Nif-mutant strains. Mol Plant Microbe Interact 14:358-366 
Simujide H, Aorigele C, Wang CJ, Manda B, Lina M, Wu MY, Li Y, Ge Bai TR (2013) Reduction of food borne pathogens during cattle manure composting with addition of calcium cyanamide. J Environ Eng Landsc 21:77-84

Spaccini R, Mazzei P, Squartini A, Giannattasio M, Piccolo A (2012) Molecular properties of a fermented manure preparation used as field spray in biodynamic agriculture. Environ Sci Pollut Res 19:4214-4225

Sreenivasa MN, Naik N, Bhat SN (2009) Beejamrutha: a source for beneficial bacteria. Karnataka J Agric Sci 22:1038-1040

Stewart EJ (2012) Growing unculturable bacteria. J Bacteriol 194:4151-4160

Tamura K, Stecher G, Peterson D, Filipski A, Kumar S (2013) MEGA6: molecular evolutionary genetics analysis version 6.0. Mol Biol Evol 30:2725-2729

Vacheron J, Desbrosses G, Bouffaud ML, Touraine B, MoenneLoccoz Y, Muller D, Legendre L, Wisniewski-Dye F, PrigentCombaret C (2013) Plant growth-promoting rhizobacteria and root system functioning. Front Plant Sci 4:356. doi:10.3389/fpls. 2013.00356

Videira S, Pereira e Silva M, Souza Galisa P, Dias A, Nissinen R, Divan V, Elsas J, Baldani J, Salles J (2013) Culture-independent molecular approaches reveal a mostly unknown high diversity of active nitrogen-fixing bacteria associated with Pennisetum purpureum-a bioenergy crop. Plant Soil 373:737-754

Yadav A, Gupta R, Garg VK (2013) Organic manure production from cow dung and biogas plant slurry by vermicomposting under field conditions. Int J Recycl Org Waste Agric 2:21. doi:10.1186/ 2251-7715-2-21

Yamada K, Xu HL (2001) Properties and applications of an organic fertilizer inoculated with effective microorganisms. J Crop Prod 3:255-268

Yan ZH, Jie L, Jing LJ, Cai LY, Fen WX, Jun CZ (2013) Microbial community dynamics during biogas slurry and cow manure compost. J Integr Agric 12:1087-1097 